\title{
Pengelolaan Sumber Daya Manusia (Tinjauan Aspek Rekrutmen dan Seleksi)
}

\author{
Nanang Nuryanta ${ }^{1}$
}

\begin{abstract}
Abstrak
Pengelolaan sumber daya manusia adalah merupakan aspek yang sangat penting dalam proses pendidikan secara umum. Oleh karena itu fungsi-fungsi dalam pengelolaan sumber daya manusia harus dilaksanakan secara optimal sehingga kebutuhan yang menyangkut tujuan individu, perusahaan, organisasi ataupun kelembagaan dapat tercapai. Disamping itu dengan prosedur pengelolaan sumber daya manusia yang baik diharapkan kekurangan dan problem yang dihadapi oleh bangsa Indonesia, yaitu yang terkait dengan kemampuan daya saing dapat teratasi.

Suatu bukti bahwa bangsa Indonesia masih belum siap untuk bersaing dalam dunia global dapat dilihat dari kemampuan daya saing sumber daya manusianya. Tenaga ahli kita belum cukup memadai untuk bersaing di tingkat global. Dilihat dari pendidikannya, angkatan kerja kita saat ini sungguh memprihatinkan. Sebagian besar angkatan kerja (53\%) tidak berpendidikan.

Mereka yang berpendidikan dasar sebanyak 34\%, berpendidikan menengah $11 \%$, dan yang berpendidikan tinggi (universitas) hanya $2 \%$. Padahal tuntutan dari dunia kerja pada akhir pembangunan pada jangka panjang II nanti mengharuskan angkatan kerja kita berpendidikan. Dari angkatan kerja yang ada hanya 11\% saja yang tidak berpendidikan; $52 \%$ berpendidikan dasar; 32\% berpendidikan menengah; dan 5\% dari angkatan kerja harus telah berpendidikan universitas.
\end{abstract}

Kata kunci: Sumber Daya Manusia, Pendidikan.

${ }^{1}$ Dosen Tetap Fakultas Ilmu Agama Islam Universitas Islam Indonesia Yogyakarta. 


\section{A. Pendahuluan}

Era globalisasi adalah era yang sedang dihadapi oleh setiap bangsa pada saat ini dan merupakan era di mana dunia menjadi terbuka dan ini menuntut kesiapan sumber daya manusia untuk semakin sadar akan adanya keterbukaan juga menuntut kesadaran akan hak dan kewajibannya sebagai insan berbudaya. Pengaruh budaya global tersebut secara disadari maupun tidak, pada suatu saat akan sampai kepada setiap bangsa di dunia, tidak terkecuali bangsa Indonesia. Oleh karenanya, apapun unsur yang terkandung di dalam era global tersebut menuntut kesiapan suatu bangsa dalam menghadapinya, khususnya kesiapan sumber daya manusianya.

Perkembangan ilmu pengetahuan dan teknologi, yang merupakan ciri era globalisasi secara eksponensial akan mengubah dengan sangat cepat cara dan gaya hidup manusia, yaitu dari masyarakat prehistoris kepada suatu masyarakat postindustri. Kondisi semacam itu secara jelas menuntut suatu bangsa untuk mempersiapkan sumber daya manusianya, khususnya melalui bidang pendidikan. Melihat fenomena pendidikan yang diselenggarakan oleh pemerintah Indonesia saat ini, perlu kiranya dilakukan reformasi pendidikan, yaitu mempersiapkan pendidikan yang mampu menghasilkan sumber daya manusia Indonesia untuk dapat berkompetisi dalam abad 21 atau abad milenium ketiga yang ditandai oleh adanya persaingan global yang sangat ketat. Jikalau pemerintah Indonesia tidak segera dapat berfikir ke depan bahwa salah satu upaya untuk mempersiapkan sumber daya manusia yang unggul ini adalah ditempuh melalui pendidikan, maka sudah barang tentu bangsa Indonesia akan selalu tertinggal dengan bangsa lain di dunia. Jadi fenomena bahwa pemerintah Indonesia masih memandang pendidikan dengan sebelah mata harus mulai direformasi. Pemerintah seyogyanya mulai memiliki polical will untuk memprioritaskan pendidikan dalam pembangunan yang sedang digalakkan saat ini, sebagai wahana untuk mempersiapkan sumber daya manusia.

Suatu bukti bahwa bangsa Indonesia masih belum siap untuk bersaing dalam dunia global dapat dilihat dari kemampuan daya saing sumber daya manusianya, sebagaimana dikemukakan oleh Boediono (1997:82) dalam Suyanto dan Hisyam (2000:3) yang menyatakan bahwa berbicara kemampuan sebagai bangsa, tampaknya kita belum siap benar menghadapi persaingan pada milenium ketiga. Tenaga ahli kita belum cukup memadai untuk bersaing di tingkat 
global. Dilihat dari pendidikannya, angkatan kerja kita saat ini sungguh memprihatinkan. Sebagian besar angkatan kerja (53\%) tidak berpendidikan. Mereka yang berpendidikan dasar sebanyak $34 \%$, berpendidikan menengah $11 \%$, dan yang berpendidikan tinggi (universitas) hanya $2 \%$. Padahal tuntutan dari dunia kerja pada akhir pembangunan pada jangka panjang II nanti mengharuskan angkatan kerja kita berpendidikan. Dari angkatan kerja yang ada hanya $11 \%$ saja yang tidak berpendidikan; $52 \%$ berpendidikan dasar; $32 \%$ berpendidikan menengah; dan 5\% dari angkatan kerja harus telah berpendidikan universitas.

Bahkan lebih khusus, Suyanto dan Hisyam (2000) menyatakan bahwa kualitas sumber daya manusia (SDM) kita masih rendah. Oleh karena itu, sebenarnya kita patut khawatir terhadap kemampuan bersaing SDM kita dalam era globalisasi dalam milenium ketiga nanti. Menurut data yang dipublikasikan oleh United Nation Development Report Programme (UNDP) yang diberi judul Human Development Report 1996, kualitas SDM kita berada pada posisi memprihatinkan. Laporan UNDP itu memuat angka indeks kualitas SDM (Human Development Index-HDI) dari 174 negara di dunia. Hasil laporan itu sangat mengejutkan dan memprihatinkan, yaitu Indonesia berada pada peringkat 102. Dapat dibayangkan betapa rendahnya daya saing Indonesia untuk memperoleh posisi kerja yang baik dalam era global. Pada tahun 1999, daya saing bangsa Indonesia tentu lebih jelek lagi. Hal ini terjadi sebagai akibat adanya krisis ekonomi dan politik yang sampai saat ini kita tidak pernah tahu kapan krisis itu akan berakhir.

Kondisi di atas, memberikan informasi kepada kita bahwa secara tegas pendidikan yang sedang dilaksanakan oleh bangsa Indonesia perlu dioptimalkan, khususnya yang menyangkut pengelolaan sumber daya manusianya. Pengelolaan sumber daya manusia ini merupakan aspek yang sangat penting untuk menunjang keberlangsungan suatu bangsa dalam dataran makro dan organisasi atau lembaga dalam dataran mikro.

Dalam setting organisasi atau perusahaan, suatu pengelolaan sumber daya manusia perlu diarahkan pada suatu model yang dapat menarik seluruh potensi sumber daya manusia tersebut bagi kepentingan organisasi atau dengan kata lain pengelolaan sumber daya manusia harus dapat diarahkan pada upaya yang mampu menggali potensi SDM agar dapat memberikan kontribusi yang positif bagi perusahaan atau organisasi. Pada kenyataannya 
pula pengelolaan ditingkat mikro, khususnya yang dilakukan oleh lembaga pemerintah (negeri) seringkali terjadi perbedaan dengan yang dilakukan oleh pihak swasta. Ini memberikan indikasi bahwa dalam pengelolaan sumber daya manusia di Indonesia secara ideal belum mempunyai standar yang jelas.

Berdasarkan latar belakang di atas, dapatlah diidentifikasikan bahwa untuk mengelola sumber daya manusia, khususnya yang dapat diarahkan untuk dapat memberikan kontribusi positif bagi lembaga atau perusahaan, maka perlu dilakukan standarisasi yang jelas. Standarisasi pengelolaan sumber daya manusia inilah yang nampaknya menjadi permasalahan yang dihadapi oleh setiap lembaga, organisasi atau perusahaan saat ini. Disamping itu masalah etika dalam mengelola sumber daya manusia ini perlu dikedepankan agar tidak menimbulkan efek negatif bagi masyarakat.

Namun demikian, karena aspek yang ada dalam pengelolaan sumber daya manusia ini cukup banyak, yaitu mencakup proses perencanaan, rekrutmen, seleksi, induksi, penilaian, pengembangan, kompensasi, bargaining, keamanan, kontinuitas dan informasi maka penulis mencoba membatasinya pembahasan masalah pada aspek rekrutmen dan seleksi saja. Dalam hal rekrutmen, masalah yang sangat mendasar yang dihadapi oleh banyak organisasi, lembaga atau perusahaan adalah bagaimana menarik para pelamar atau peminat pekerjaan agar dapat bekerja secara optimal dalam perusahaan, bahkan lebih dari itu para pekerja nantinya dapat menopang keberlangsungan organisasi, lembaga atau perusahaan dimana mereka bekerja bahkan setelah mereka bekerja. Karena kenyataannya rekrutmen yang banyak dilakukan oleh lembaga, perusahaan dan organisasi tertentu cenderung hanya pada taraf pendaftaran atau registration saja. Sehinga kualifikasi pekerja yang diharapkan tidak berhasil didapatkan. Belum lagi proses rekrutmen dan seleksi yang dilakukan perusahaan kadangkala justru mengabaikan aspek etika dalam melakukan rekrutmen dan seleksi. Suatu bukti yang menarik dan aktual di era reformasi pada bangsa Indonesia, adalah kecenderungan pada setiap rekrutmen dan seleksi pegawai, baik pada instansi pemerintah maupun swasta, yang masih mengunakan prinsip kolusi, korupsi, dan nepotisme (KKN). Bahkan prinsip utama rekrutmen dan seleksi, yang menuntut kualifikasi calon pelamar yang memenuhi syarat untuk bekerja, seringkali harus rela dan "digagalkan" untuk bekerja karena tidak berani membayar dengan mahal. Ini berarti bahwa uang cukup memainkan peran yang tinggi dalam proses rekrutmen dan seleksi 
pada segmen organisasi, perusahaan atau lembaga apapun di Indonesia. Kalau pun ada perusahaan, lembaga atau organisasi yang bersih dari praktek KKN dan "main uang" di Indonesia saat ini tentu persentasenya sangat kecil, bahkan hampir tidak ada. Hal ini sangat "naif" sekali bila dikembalikan pada semangat reformasi yang akan berupaya menghapus KKN, tetapi pada kenyataannya justru praktek tersebut masih berjalan dengan subur. Sebagai akibatnya kualitas kinerja perusahaan juga rendah dan tidak mempunyai kemampuan daya saing dengan perusahaan lainnya, apalagi dengan perusahaan yang sudah bonafit, demikian pula dalam scope pengelolaan sumber daya manusia secara makro. Ini menunjukkan bahwa pendidikan yang dilakukan di Indonesia belum mampu memberikan landasan yang kuat bagi proses penanaman nilai-nilai luhur bagi sumber daya manusia Indonesia.

Namun demikian dalam makalah ini penulis tidak akan mengarahkan pembahasan paper ini pada suatu kondisi obyektif, misalnya perusahaan atau lembaga pendidikan tertentu, dengan alasan agar paper ini dapat menjadi "term paper" yang applicable untuk organisasi, perusahaan, atau lembaga manapun yang memerlukannya. Untuk itulah dalam makalah singkat ini penulis hanya akan mencoba membahas mengenai pengelolaan sumber daya manusia secara umum, tinjauan mengenai rekrutmen dan seleksi dan diakhiri dengan kesimpulan.

\section{B. Tinjauan Mengenai Pengelolaan Sumber Daya Manusia}

\section{Konsep Pengelolaan Sumber Daya Manusia}

Pengelolaan sumber daya manusia dalam istilah lain sering disebut: "personal management"; "personal administration"; "human resources administration". (Umi Sukamti, 1989:4). Beberapa istilah tersebut dalam bidang pendidikan merupakan salah satu substansi dari manajemen pendidikan.

Untuk memperjelas konsep pengelolaan sumber daya manusia, perlu kiranya penulis menampilkan beberapa pandangan dari para pakar sebagai berikut.

Edwin B. Flippo (1984) menyatakan bahwa pengelolaan sumber daya manusia merupakan proses perencanaan, pengorganisasian, pengarahan dan pengendalian dari pengadaan tenaga kerja, 
pengembangan, kompensasi, integrasi, pemeliharaan dan pemutusan hubungan kerja dengan maksud untuk mencapai tujuan atau sasaran perorangan, organisasi, dan masyarakat.

Menurut Haneman (1989:2) menyatakan bahwa: "Personal or human resources management is a set of organization wide function or activities that are designed to influence the activitievness if employees in the organization". Sedangkan menurut Wayne dan Elias (1981:3) "human resources management is the attraction, selection, retention, development, and utilization of human resources in order to achieve both individual and organization objectives".

\section{Fungsi Pengelolaan Sumber Daya Manusia.}

Pengelolaan sumber daya manusia pada dasarnya merupakan deskripsi dari administrasi atau manajemen pendidikan dengan mengidentifikasi fungsi-fungsinya sebagai suatu setting proses administrasi atau manajemen pendidikan yang didesain untuk saling berkaitan antara tujuan individu maupun organisasi. Menurut Castetter (1981:3) proses administrasi atau manajemen tersebut meliputi planning, recruitment, selection, induction, appraisal, development, compensation, bargaining, security, continuity, and information. Sedangkan Randall (1987:29) mengindentifikasikan fungsi-fungsi tersebut ke dalam proses sumber daya manusia yang meliputi "planning, staffing, appraising, compensation, and training".

Dari beberapa definisi dan konsep pengelolaan sumber daya manusia di atas dapat dipahami bahwa suatu pengelolaan sumber daya manusia merupakan suatu proses yang berhubungan dengan implementasi indikator fungsi-fungsi pengelolaan atau manajemen yang berperan penting dan efektif dalam menunjang tercapainya tujuan individu, lembaga, maupun organisasi atau perusahaan.

Bagi suatu organisasi, pengelolaan sumber daya manusia menyangkut keseluruhan urusan organisasi dan tujuan yang telah ditetapkan. Untuk itu seluruh komponen atau unsur yang ada di dalamnya, yaitu para pengelola dengan berbagai aktifitasnya harus memfokuskan pada perencanaan yang menyangkut penyusunan staff, penetapan program latihan jabatan dan lain sebagainya. Hal ini perlu dilakukan untuk mengantisipasi perkembangan jangka pendek dan jangka panjang dari suatu organisasi tersebut, khususnya yang menyangkut kesiapan sumber daya manusianya. Alasan lainnya 
adalah bahwa suatu pengelolaan sumber daya manusia dalam suatu organisasi tidak dapat terlepas dari lingkungan internal maupun eksternal, yang pada suatu saat akan dapat mempengaruhi keberadaan organisasi tersebut.

\section{Rekrutmen dan Seleksi Sumber Daya Manusia}

Diantara beberapa unsur dari pengelolaan sumber daya manusia yang sangat terkait dengan keberadaan organisasi atau perusahaan adalah unsur rekrutmen dan seleksi SDM. Untuk lebih memperjelas mengenai beberapa konsep tentang rekrutmen dan seleksi, berikut ini akan dipaparkan mengenai kedua hal tersebut.

\section{Rekrutmen}

Menurut Randall S. Schuler dan Susan E. Jackson (1997:227) rekrutmen antara lain meliputi upaya pencarian sejumlah calon karyawan yang memenuhi syarat dalam jumlah tertentu sehingga dari mereka perusahaan dapat menyeleksi orang-orang yang paling tepat untuk mengisi lowongan pekerjaan yang ada. Sebagai akibatnya rekrutmen tidak hanya menarik simpati atau minat seseorang untuk bekerja pada perusahaan tersebut, melainkan juga memperbesar kemungkinan untuk mempertahankan mereka setelah bekerja. Jadi intinya rekrutmen merupakan usaha yang dilakukan untuk memperoleh sumber daya manusia yang dibutuhkan dalam mengisi jabatan-jabatan terntu yang masih kosong. Selain itu rekrutmen merupakan usaha-usaha mengatur komposisi sumber daya manusia secara seimbang sesuai dengan tuntutan melalui penyeleksian yang dilakukan.

Melalui rekrutmen organisasi dapat melakukan komunikasi dengan pihak-pihak tertentu untuk memperoleh sumber daya manusia yang potensial, sehingga akan banyak pencari kerja dapat mengenal dan mengetahui organisasi yang pada akhirnya akan memutuskan kepastian atau tidaknya dalam bekerja. Dengan rekrutmen diharapkan pencari kerja yang berkualitas tinggi akan mengetahui adanya kesempatan kerja. Selain itu perlu juga diusahakan adanya kesan dan image yang positif mengenai organisasi dengan memberikan informasi yang cukup mengenai pekerjaan sehingga pencari kerja dapat mempertimbangkan minat dan kualifikasinya. Menurut Umi Sukamti (1989), dalam proses rekrutmen terdiri dari 
dua fase, yaitu: (a) untuk memonitor perubahan lingkungan dan organisasi yang menimbulkan kebutuhan sumber daya manusia baru, dan menetapkan pekerjaan-pekerjaan yang harus diisi dan tipe-tipe pelamar yang diperlukan; (b) untuk menyebarluaskan kepada pelamar yang potensial bahwa ada lowongan pekerjaan, sehingga menarik pelamar yang bersangkutan dan menyisihkan pelamar yang kurang memenuhi kualifikasi yang diperlukan.

Lebih lanjut Randall S. Schuler dan Susan E. Jackson (1997:227) menjelaskan bahwa kegiatan kunci yang merupakan bagian dari rekrutmen adalah (1) menentukan kebutuhan jangka pendek dan jangka panjang perusahaan dalam hal jenis pekerjaan (job title) dan levelnya dalam perusahaan; (2) terus berupaya mendapatkan informasi mengenai perkembangan kondisi pasar tenaga kerja; (3) menyusun bahan-bahan rekrutmen yang efektif; (4) menyusun program rekrutmen yang sistematis dan terpadu yang berhubungan dengan kegiatan sumber daya manusia lain dan dengan kerja sama antara manajer lini dan karyawan; (5) mendapatkan pool calon karyawan yang berbobot atau memenuhi syarat; (6) mencatat kualitas dan jumlah pelamar dari berbagai sumber dan masing-masing metode rekrutmennya; dan (7) melakukan tindak lanjut terhadap para calon karyawan baik yang diterima maupun yang ditolak, guna mengevaluasi efektif tidaknya rekrutmen yang dilakukan. Dan yang paling penting semua kegiatan ini harus dilakukan sesuai konteks hukum yang berlaku.

Adapun hasil kegiatan rekrutmen adalah identifikasi terhadap suatu pool yang berisikan para calon karyawan yang memenuhi syarat yang kemungkinan besar akan terpilih dan ditempatkan. Meskipun demikian, ternyata dalam kenyataannya rekrutmen belum tentu berhasil dengan baik, hal ini sangat terkait dengan berbagai kendala yang dihadapi. Menurut Sondang P. Siagaan (1999) berbagai kendala yang dihadapi menurut berbagai penelitian dan pengalaman banyak orang dalam hal rekrutmen menunjukkan bahwa kendala yang biasa dihadapi itu dapat mengambil tiga bentuk, yaitu kendala yang bersumber dari organisasi yang bersangkutan sendiri, kebiasaan pencari tenaga kerja sendiri dan faktor-faktor eksternal yang bersumber dari lingkungan di mana organisasi bergerak.

Lebih jelasnya, ketiga faktor tersebut dapat digambarkan pada tabel di bawah ini: 


\begin{tabular}{|c|c|c|}
\hline $\begin{array}{c}\text { Faktor } \\
\text { Organisasional }\end{array}$ & $\begin{array}{c}\text { Kebiasaan Pencari } \\
\text { Tenaga Kerja }\end{array}$ & $\begin{array}{l}\text { Kondisi Eksternal } \\
\text { (Lingkungan) }\end{array}$ \\
\hline $\begin{array}{l}\text { 1. Kebijaksanaan } \\
\text { Promosi dari } \\
\text { dalam. } \\
\text { 2. Kebijaksanaan } \\
\text { tentang imbalan, } \\
\text { yang tergantung } \\
\text { pada: } \\
\text { 3. Kepentingan para } \\
\text { anggota organisasi. } \\
\text { 4. Kemampuan } \\
\text { organisasi yang } \\
\text { bersangkutan. } \\
\text { 5. Keharusan } \\
\text { mentaati berbagai } \\
\text { peraturan } \\
\text { perundangan. } \\
\text { 6. Pertimbangan } \\
\text { lokasi. } \\
\text { 7. Kebijaksanaan } \\
\text { tentang status } \\
\text { kepegawaian. } \\
\text { 8. Rencana sumber } \\
\text { daya manusia. }\end{array}$ & $\begin{array}{l}\text { Pada satuan kerja yang } \\
\text { mengelola sumber daya } \\
\text { manusia biasanya ada } \\
\text { tenaga spesialis yang terdiri } \\
\text { dari sekelompok orang yang } \\
\text { tugasnya adalah melakukan } \\
\text { rekrutmen. Tenaga spesialis } \\
\text { ini mempunyai dua segi: } \\
\text { 1. Segi Positifnya, yaitu } \\
\text { proses rekrutmen dapat } \\
\text { berlangsung dengan cepat } \\
\text { karena pengetahuan dan } \\
\text { pengalamannya mengenai } \\
\text { kualifikasi tenaga kerja } \\
\text { yang dibutuhkan. } \\
\text { 2. Segi negatipnya, yaitu } \\
\text { kecenderungan untuk } \\
\text { berbuat kesalahan dalam } \\
\text { merekrut pegawai bila } \\
\text { tidak berpengaruh pada } \\
\text { organisasi dan juga sikap } \\
\text { yang sering menganggap } \\
\text { enteng terhadap usaha } \\
\text { rekrutmen, khususnya } \\
\text { berkaitan dengan } \\
\text { persyaratan kuantitas } \\
\text { pelamar. }\end{array}$ & $\begin{array}{l}\text { 1. Tingkat pengangguran. } \\
\text { 2. Kedudukan organisasi } \\
\text { pencari tenaga kerja } \\
\text { terhadap organisasi/ } \\
\text { perusahaan lain yang } \\
\text { bergerak pada bidang yang } \\
\text { sama dan menghasilkan } \\
\text { produk sejenis. } \\
\text { 3. Langka tidaknya keahlian } \\
\text { atau ketrampilan tertentu. } \\
\text { 4. Proyeksi angkatan kerja } \\
\text { pada umumnya. } \\
\text { 5. Peraturan perundang- } \\
\text { undangan di bidang } \\
\text { ketenagakerjaan. } \\
\text { 6. Praktek rekrutmen oleh } \\
\text { organisasi lain. } \\
\text { 7. Tuntutan tugas yang kelak } \\
\text { akan dikerjakan oleh para } \\
\text { pekerja baru itu, yang } \\
\text { menyangkut: persyaratan } \\
\text { khusus, pengalaman kerja } \\
\text { sebelumnya, tenaga, waktu } \\
\text { dan biaya yang besar, } \\
\text { persepsi terhadap imbalan, } \\
\text { dan juga tenaga kerja yang } \\
\text { telah terekrut ternyata } \\
\text { tidak memenuhi kualifikasi } \\
\text { yang ditetapkan. }\end{array}$ \\
\hline
\end{tabular}

Sebagaimana telah disebutkan sebelumnya bahwa rekrutmen dimaksudkan untuk mendapatkan calon karyawan yang memenuhi syarat. Oleh karena itu proses rekrutmen hendaknya perlu memperhatikan sumber-sumber yang dapat dijadikan wahananya, yaitu meliputi sumber internal dan sumber eksternal. Menurut Randall S. Schuler dan Susan E. Jackson (1997) sumber-sumber dan metode tersebut adalah:

a. Sumber internal. Sumber-sumber internal meliputi karyawan yang ada sekarang yang dapat dicalonkan untuk dipromosikan, dipindahtugaskan atau dirotasi tugasnya, serta mantan karyawan yang bisa dikaryakan dan dipanggil kembali. Adapun metode yang dapat digunakan adalah dengan menempelkan pemberitahuan pada papan pengumuman, pengumuman lisan, penelitian riwayat kerja karyawan (personnel records), penelitian daftar promosi berdasarkan kinerja, melakukan pemeringkatan dari kegiatan penilaian, melakukan pengecekan daftar senioritas, dan melihat daftar yang dibuat menurut ketrampilan pada Sistem Informasi Sumber Daya Manusia perusahaan. Itu semua dapat dilakukan 
dengan membuat job posting dan daftar ketrampilan (skill inventories).

b. Sumber eksternal, adalah sumber untuk mendapatkan karyawan dari luar perusahaan yang memiliki bobot atau kualifikasi tertentu. sumber yang dapat dilakukan adalah dengan program referal karyawan, yaitu iklan secara lisan; walk-in apllicant, di mana sejumlah pelamar mencalonkan diri dengan mendatangi langsung bagian rekrutmen di perusahaan tersebut; melalui biro-biro tenaga kerja; melalui perusahaan lain; melaui birobiro bantuan sementara; melalui asosiasi dan serikat dagang; sekolah, WNA (warga negara asing). Adapun metode yang dapat digunakan adalah melalui iklan radio dan televisi, iklan di koran dan jurnal perdagangan, Computerized Service Listings, akuisisi dan merger, open house, rekrutmen berdasarkan kontrak (contract recruiting), Contingent Workforce Recruiting (perekrutan tenaga kerja sementara).

Selain melalui metode yang telah disebutkan oleh Randall S. Schuler dan Susan E. Jacson tersebut, Sondang P. Siagian (1999) juga menambahkan berbagai sumber metode yaitu melalui perusahaan pencari tenaga kerja profesional, organisasi profesi, dan balai latihan kerja milik pemerintah.

Untuk mendukung suatu rekrutmen agar dapat berjalan dengan baik maka perlu adanya legalisasi hukum. Hal ini untuk memberikan jaminan perlindungan bagi perusahaan atau organisasi yang melakukan rekrutmen maupun bagi calon pelamar, khususnya berkaitan dengan asas keadilan. Oleh karena itu di Indonesia pun, masalah undang-undang ketenagakerjaan ini telah dibuat sebagai upaya untuk melindungi hak-hak dan kewajiban pekerja.

Untuk lebih memperjelas hubungan pada aspek rekrutmen dalam pengelolaan sumber daya manusia dapat dilihat pada gambar di bawah ini: 


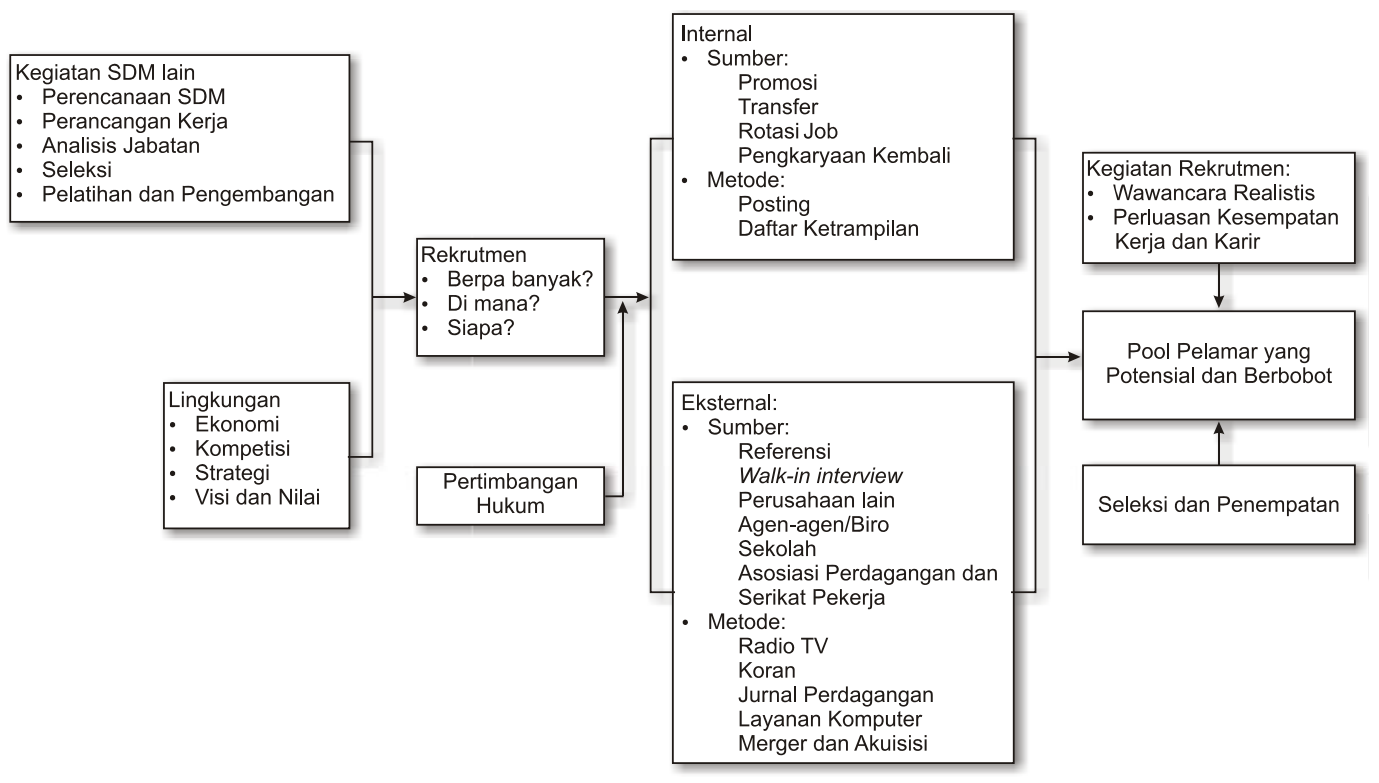

Gambar 1:

Sumber: dari Randall S. Schuler dan Susan E. Jackson (1997). Manajemen Sumber Daya Mnusia Menghadapi Abad Ke-21. Jakarta: Penerbit Erlangga, hal. 231

Berdasarkan gambaran di atas dan penjelasan sebelumnya, ada beberapa aspek penting yang merupakan bagian dari rekrutmen, antara lain berupa penetapan kebutuhan sumber daya manusia baik dalam jangka pendek maupun jangka panjang dan aspek lainnya berupa pengembangan efektifitas rekrutmen, upaya memperoleh kualifikasi pelamar dan lain sebagainya. Menurut Randall (1987:125) esensi dari efektivitas rekrutmen adalah membantu lembaga dalam memperoleh tujuan umum yang meliputi produktivitas kerja, kualitas kehidupan kerja, dan kepatuhan kerja.

\section{Seleksi}

Proses seleksi merupakan salah satu bagian yang terpenting dalam keseluruhan proses manajemen sumber daya manusia. Pernyataan ini didasarkan pada suatu alasan bahwa suatu organisasi ataupun perusahaan akan mendapatkan sejumlah pegawai yang memenuhi kualifikasi yang dipersyaratkan atau tidak adalah sangat tergantung pada cermat tidaknya proses seleksi ini dilakukan. Dan proses seleksi ini merupakan bagian yang tidak bisa dipisahkan dengan rekrutmen. 
Menurut Umi Sukamti (1989:153) mendefinisikan seleksi sebagai suatu proses penetapan pelamar yang mana diantara mereka direkrut dengan melalui pertimbangan persyaratan-persyaratan untuk dapat diterima dalam melakukan pekerjaan dengan baik.

Sedangkan menurut Randall S. Schuler dan Susan E. Jackson (1997), yang mengaitkan seleksi dan penempatan menyebutkan bahwa seleksi adalah proses mendapatkan dan mempergunakan informasi mengenai pelamar kerja untuk menentukan siapa yang seharusnya diterima menduduki posisi jangka pendek dan jangka panjang. Penempatan (placement) berkaitan dengan pencocokan seseorang dengan jabatan yang akan dipegangnya, berdasarkan pada kebutuhan jabatan dan pengetahuan, ketrampilan, kemampuan, preferensi, dan kepribadian karyawan tersebut.

Berdasarkan definisi tersebut, dapat dipahami bahwa seleksi merupakan salah satu cara yang dilakukan organisasi atau perusahaan untuk melihat kesesuaian atau tidaknya antara individu, pekerjaan, organisasi, dan lingkungan. Oleh karena itu, prosedur seleksi yang cermat dan penempatan yang sesuai adalah merupakan esensi dari pengelolaan sumber daya manusia dalam suatu perusahaan atau organisasi. Jikalau dilakukan dengan baik, niscaya prosedur ini akan menjamin bahwa sebuah perusahaan atau organisasi mempunyai karyawan yang dapat menjalankan tugasnya dengan baik dan menghasilkan produktivitas yang tinggi. Namun demikian, dalam proses seleksi menurut Sondang P. Siagian (1999:133) ada empat macam tantangan yang perlu diperhatikan dan dihadapi oleh para petugas seleksi dalam menentukan jenis dan langkah-langkah dalam proses seleksi, yaitu: penawaran tenaga kerja, tantangan etis, tantangan organisasional, dan kesamaan kesempatan memperoleh pekerjaan.

Lebih lanjut (Sondang P. Siagian, 1999:133) menjelaskan bahwa langkah-langkah dalam proses seleksi minimal ada delapan langkah, yaitu:

a. penerimaan surat lamaran,

b. penyelenggaraan ujian,

c. wawancara seleksi,

d. pengecekan latar belakang pelamar dan surat-surat referensinya,

e. evaluasi kesehatan,

f. wawancara oleh manajer yang akan menjadi atasan langsungnya,

g. pengenalan pekerjaan, dan 
h. keputusan atas lamaran.

Sedangkan tentang isi langkah-langkah seleksi, menurut Randall S. Schuler dan Susan E. Jackson (1997:264-285), yang didasarkan pada hasil riset tentang reaksi pelamar dalam prosedur seleksi menunjukkan bahwa pelamar lebih menyukai proses yang melibatkan mereka dalam kegiatan yang benar-benar berkaitan dengan lowongan pekerjaan. Bagi pelamar, simulasi dan contoh kerja biasanya dianggap lebih relevan daripada tes kognitif tertulis dan analisis tulisan tangan misalnya, dan mungkin karena alasan ini, pelamar menganggap cara seperti itu lebih adil. Pelamar mungkin bereaksi negatif terhadap wawancara yang dilakukan secara buruk. Pertanyaan diskriminatif atau menyerang jelas menimbulkan kesan negatif. Demikian juga pertanyaan dangkal dan tak berkaitan dengan masalahnya.

Untuk itulah dalam upaya mendapatkan berbagai informasi untuk meramalkan performasi, organisasi seharusnya mengupayakan berbagai alat seleksi dari yang biasa dipakai dan yang tidak biasa dipakai. Dalam hal ini menurut Umi Sukamti (1989:164) ada empat standar yang dapat digunakan organisasi dalam proses seleksi, yaitu: (a) relevansi, yaitu sejauhmana alat seleksi dapat mencerminkan sampel yang representatif dari pekerjaan; (b) reliabilitas, yaitu sejauhmana suatu alat seleksi memberikan hasil yang sama apabila dipakai dalam waktu yang tidak sama atau oleh orang yang berbeda; (c) validitas, yaitu hubungan statis antara skor-skor pada alat seleksi dengan kriteria atau ukuran performasi pekerjaan; dan (d) faktor keadilan, yaitu setiap alat seleksi harus dinilai standar keadilannya yang mana kecenderungan alat ini memperlakukan dan memberi kesempatan sama kepada semua pelamar untuk mendapatkan pekerjaan.

Dari berbagai penjelasan dan konsep mengenai seleksi tersebut, apabila dilakukan dengan prosedur yang benar dan didukung dengan alat seleksi yang tepat dan akurat, sudah barang tentu kualifikasi sumber daya manusia yang dibutuhkan oleh setiap organisasi akan dapat terpenuhi. Karena prosedur yang benar dalam melakukan seleksi ini akan mempunyai dampak positif bukan saja bagi perusahaan tetapi juga bagi para pelamar pekerjaan yang diseleksi. Bagi perusahaan keuntungan yang dapat diperoleh adalah mudah untuk menentukan kualifikasi pelamar yang dinyatakan lolos seleksi. Sedangkan keuntungan bagi para pelamar adalah dapat merasa puas dan tidak menimbulkan kecurigaan-kecurigaan dalam proses seleksi. Pelamar akan merasakan adanya sikap dan tindakan yang 
fair dari perusahaan atau organisasi penyelenggara seleksi, sehingga apabila pelamar mengalami kegagalan dalam seleksi, mereka akan dapat merasakan "kepuasan" atau paling tidak dapat mengadakan introspeksi diri bahwa mereka belum dapat memenuhi standar yang ditentukan oleh perusahaan atau organisasi untuk bekerja.

Seangkan bagi para pelamar yang dapat lolos dalam seleksi, tentunya mereka diharapkan dapat bekerja sesuai dengan job spesifikasinya masing-masing yang pada akhirnya dapat menampilkan seluruh potensi yang dimilikinya, baik itu berupa pengetahuan, kemampuan, ketrampilan, minat, kesukaan, dan kepribadiannya bagi kepentingan dan tujuan perusahaan atau organisasi tempat mereka bekerja.

\section{Kesimpulan}

Setelah mencermati latar belakang permasalahan dan pembahasan mengenai pengelolaan sumber daya manusia, khususnya yang berkenaan dengan aspek rekrutmen dan seleksi, maka penulis dapat menarik beberapa kesimpulan:

1. Pengelolaan sumber daya manusia adalah merupakan aspek yang sangat penting dalam proses pendidikan secara umum. Oleh karena itu fungsi-fungsi dalam pengelolaan sumber daya manusia harus dilaksanakan secara optimal sehingga kebutuhan yang menyangkut tujuan individu, perusahaan, organisasi ataupun kelembagaan dapat tercapai. Disamping itu dengan prosedur pengelolaan sumber daya manusia yang baik diharapkan kekurangan dan problem yang dihadapi oleh bangsa Indonesia, yaitu yang terkait dengan kemampuan daya saing dapat teratasi.

2. Rekrutmen yang merupakan upaya untuk menghasilkan suatu pool pelamar kerja untuk ditempatkan pada posisi pekerjaan yang lowong diperoleh melalui sumber eksternal maupun internal. Rekrutmen harus diupayakan untuk dapat memenuhi kebutuhan perusahaan, individu pelamar dan masyarakat. Kebutuhan individu dalam rekrutmen ini mempunyai dua aspek, yaitu menarik calon pelamar dan mempertahankan karyawan yang diinginkan. Untuk melakukan rekrutmen hendaknya perusahaan benar-benar mempertimbangkan pelamar yang benar-benar memiliki potensi yang unggul dan memenuhi persyaratan serta harus disesuaikan dengan jumlah yang diperlukan sehingga orang yang terpilih benar-benar sesuai dengan pekerjaanya. 
3. Seleksi yang dilakukan oleh perusahaan, organisasi ataupun lembaga tertentu harus dapat dipastikan bahwa sumber daya manusia yang terseleksi tersebut adalah orang yang mampu memenuhi kebutuhan kerja dan dapat bekerja di perusahaan. Oleh karena itu, perusahaan ingin menyesuaikan antara kebutuhan pelamar dan imbalan yang ditawarkan menurut kualitas kerja dan konteks perusahaan. Untuk menyesuaikan pengetahuan, ketrampilan, dan kemampuan seseorang terhadap kebutuhan kerja dan untuk menyesuaikan kepribadian, minat, dan kesukaan seseorang dengan kerja dan karakteristik perusahaan maka perusahaan harus mampu mengumpulkan informasi tentang para pelamar. Dengan informasi yang jelas tersebut perusahaan dapat melakukan penempatan pelamar sesuai dengan kemampuan, pengetahuan dan ketrampilannya atau dapat dikatakan bahwa perusahaan akan dapat menentukan pelamar sesuai dengan job spesifikasinya yang pada akahirnya akan mampu memberikan kontribusi positif bagi produktivitas perusahaan.

\section{DAFTAR PUSTAKA}

Cascio K. Wayne dan Awad A. Yulk. (1981). Human Resources Management: An Information System Approach. Virginia: Reston Publishing Company. Inc.

Castetter, W.B. (1982). The Personnel Function in Education Administration. New York: Mac Millan Publishing Co. Inc.

Flippo B. Edwin. (1984). The Personnel Management. Mc Graw Hill Book Company.

Haneman H.G. (1981). Managing Personnel and Human Resources: Strategies and Programs. Illinois: Richard D. Irwin Inc.

Randall S. Schuler. (1987). Personnel and Human Resources Management. New York University: Kelogg Borkvard.

Randall S. Schuler dan Susan E. Jackson. (1997). Manajemen Sumber Daya Manusia Menghadapi Abad Ke-21 Jilid 1. Edisi Keenam. Jakarta: Penerbit Erlangga.

Siagian, Sondang P. (1999). Manajemen Sumber Daya Manusia. Jakarta: Bumi Aksara.

Suyanto dan Hisyam, Djihad. (2000). Refleksi Dan Reformasi Pendidikan Di Indonesia Memasuki Milenium III, Yogyakarta: Adicita Karya Nusa.

Sukamti, Umi. (1989). Management Personalia/Sumber Daya Manusia. Jakarta: P2LPTK Dikti Depdikbud. 